Educational case report

\title{
Epithelial growth factor receptor (EGFR)-inhibition for relief of neuropathic pain-A case series
}

\author{
Christian Kersten $^{\mathrm{a}, *}$, Marte Grønlie Cameron ${ }^{\mathrm{b}, *, 1}$, Svein Mjåland ${ }^{\mathrm{b}, 2}$ \\ a Center for Cancer Treatment, Sørlandet Hospital Trust, Serviceboks 416, 4604 Kristiansand, Norway \\ b Center for Cancer Treatment, Sørlandet Hospital Trust, Kristiansand, Norway
}

\section{A R T I C L E I N F O}

\section{Article history:}

Received 20 November 2012

Accepted 25 November 2012

\section{Keywords:}

Neuropathic pain

Chronic pain

EGFR inhibition

\begin{abstract}
A B S T R A C T
Background: Neuropathic pain remains a significant challenge with unsatisfactory therapeutic options. Its pathogenesis may involve the neuropathic triad of neuronal, glial and immune cells. Communication between these cells is possibly perpetuated by mitogen-activated protein kinase (MAPK)-signaling. For several years, we successfully treated a rectal cancer patient with the epithelial growth factor receptor (EGFR)-inhibitor cetuximab, for debilitating neuropathic pain due to progressive malignant invasion of the sacral plexus. Here, we report the effect of treatment with various EGFR-inhibitors in five additional patients with severe and long-standing, therapy-resistant neuropathic pain.

Methods: All patients had well-documented neuropathic pain syndromes with the following etiologies: inflammatory polyneuropathy, complex regional pain syndrome type 1 , radiculopathy after failed back surgery, malignant invasion of the sacral plexus by bladder cancer, and phantom limb pain. All patients were given intravenous (extracellular) EGFR-inhibitors (cetuximab, panitumumab) initially, and switched to oral (intracellular) agents (gefitinib, erlotinib) after an analgesic effect was obtained.

Results: Four of the five patients responded, all within $24 \mathrm{~h}$ of intravenous administration, with a mean decrease in worst pain from 9 to 1 on a 10-point scale. All four EGFR-inhibitors were effective. The clinical courses, including patient-reported pain relief, are prospectively documented with 78-219 days follow-up for those who responded to treatment. Toxicities were transient and manageable.

Conclusions/implications: EGFR-inhibition resulted in dramatic relief of neuropathic pain. A plausible biological explanation involves the interruption of MAPK-signaling. The role of EGFR-inhibition as a target for the treatment of neuropathic pain appears promising and warrants investigation.
\end{abstract}

(C) 2012 Scandinavian Association for the Study of Pain. Published by Elsevier B.V. All rights reserved.

\section{Introduction}

Neuropathic pain (NP) is caused by a primary lesion or disease of the somatosensory system [1]. Not uncommonly, its severity, chronicity and the poor side-effect to benefit ratio of current pharmacotherapy for NP [2] lead to severely impaired physical and psychological functioning [3]. In the general population, the incidence of NP is estimated to be $1 \%$ and rising [4]. The resulting

DOI of refers to article: http://dx.doi.org/10.1016/j.sjpain.2012.11.012.

Abbreviations: NP, neuropathic pain; MAPK, mitogen-activated protein kinase; EGFR, epidermal growth factor receptor; CRPS1, complex regional pain syndrome type I; PLP, phantom-limb pain; ILD, interstitial lung disease; HER, human epidermal growth factor receptor; RTKs, receptor tyrosine kinases.

* Corresponding authors. Tel.: +4791339443.

E-mail addresses: christian.kersten@sshf.no (C. Kersten), marte.cameron@sshf.no (M.G. Cameron), svein.mjaaland@sshf.no (S. Mjåland).

1 Tel.: +4793671793.

2 Tel.: +4738146600 . prevalence of moderate to severe chronic NP is 5\% [5], making it a common and formidable health problem.

Despite the numerous etiologies of NP, the mechanism of its perpetuation appears to involve the interaction of neuronal, glial and immune cells [6]. Communication between these cells has been attributed to signaling via the family of mitogen-activated protein kinase (MAPK) proteins [7].

We recently reported the repetitive dramatic relief of NP in a rectal cancer patient treated with cetuximab [8], a monoclonal antibody against the epidermal growth factor receptor (EGFR), which consequently inhibits MAPK-signaling [9].

Since EGFR-inhibitors are approved oncologic drugs with primarily transient and manageable side effects, we have offered this treatment to five additional patients with chronic, debilitating and therapy-resistant NP.

\section{Case series}

The patients in this series have all had longstanding and debilitating NP. The NP syndromes of the responders can be classified as 
Table 1

Baseline characteristics and previous treatments of the patients.

\begin{tabular}{|c|c|c|c|c|c|c|}
\hline Case & Age, sex & Neuropathic pain history & $\begin{array}{l}\text { Pain detect } \\
\text { score }^{\text {b }}\end{array}$ & $\begin{array}{l}\text { Severe functional impairment } \\
\text { according to BPI }\end{array}$ & Treating physicians & $\begin{array}{l}\text { Previous treatments for } \\
\text { neuropathic pain }\end{array}$ \\
\hline 1 & 53 , male & $\begin{array}{l}\text { Six-year history of } \\
\text { progressive peripheral } \\
\text { polyneuropathy of unclear } \\
\text { etiology (possibly } \\
\text { Borrelia-related). }\end{array}$ & $30 / 38$ & $\begin{array}{l}\text { - General activity: } 9 \\
\text { - Mood: } 9 \\
\text { - Walking ability: } 10 \\
\text { - Normal work: } 10 \\
\text { - Relationships: } 8 \\
\text { - Sleep: } 9 \\
\text { - Enjoyment of life: } 8\end{array}$ & $\begin{array}{l}\text { Primary care physician } \\
\text { Neurologist } \\
\text { Rheumatologist } \\
\text { Anesthesiologist } \\
\text { Tertiary care pain unit }\end{array}$ & $\begin{array}{l}\text { Paracetamol } \\
\text { NSIADs } \\
\text { Steroids } \\
\text { Antiepileptics } \\
\text { Antidepressants }{ }^{\mathrm{a}} \\
\text { Healing } \\
\text { KIOVIG (ivig) } \\
\text { Physical exercise-(distraction } \\
\text { therapy) }^{\mathrm{a}}\end{array}$ \\
\hline 2 & 53 , female & $\begin{array}{l}\text { Eight-month history of } \\
\text { complex regional pain } \\
\text { syndrome type } 1 \text { (CRPS1) } \\
\text { of the right hand. }\end{array}$ & $31 / 38$ & $\begin{array}{l}\text { - General activity: } 10 \\
\text { - Mood: } 5 \\
\text { - Walking ability: } 0 \\
\text { - Normal work: } 10 \\
\text { - Relationships: } 5 \\
\text { - Sleep: } 10 \\
\text { - Enjoyment of life: } 7\end{array}$ & $\begin{array}{l}\text { Primary care physician } \\
\text { Orthopedic surgeon } \\
\text { Neurologist } \\
\text { Rheumatologist } \\
\text { Anesthesiologist } \\
\text { Tertiary care pain unit }\end{array}$ & $\begin{array}{l}\text { Paracetamol }^{\mathrm{a}} \\
\text { NSIADs }^{\mathrm{a}} \\
\text { Steroids }^{\mathrm{a}} \\
\text { Weak opioids }^{\mathrm{a}} \\
\text { Antiepileptics }^{\mathrm{a}} \\
\text { Antidepressants } \\
\text { Nerve blocks } \\
\text { Clonidine } \\
\text { Physical therapy }\end{array}$ \\
\hline 3 & 63 , male & $\begin{array}{l}\text { Eight-month history of } \\
\text { radiculopathy due to failed } \\
\text { back surgery syndrome } \\
\text { (FBSS) with scar tissue } \\
\text { formation at the L4/L5 } \\
\text { level. }\end{array}$ & $26 / 38$ & $\begin{array}{l}\text { - General activity: } 10 \\
\text { - Mood: } 8 \\
\text { - Walking ability: } 9 \\
\text { - Normal work: } 9 \\
\text { - Relationships: } 8 \\
\text { - Sleep: } 8 \\
\text { - Enjoyment of life: } 8\end{array}$ & $\begin{array}{l}\text { Primary care physician } \\
\text { Neurosurgeon }\end{array}$ & $\begin{array}{l}\text { Antiepileptics } \\
\text { Opioids }\end{array}$ \\
\hline 4 & 57 , male & $\begin{array}{l}\text { Twenty-month history of a } \\
\text { bladder cancer recurrence } \\
\text { invading pelvic organs, } \\
\text { muscles and sacral nerve } \\
\text { roots. }\end{array}$ & $24 / 38$ & $\begin{array}{l}\text { - General activity: } 9 \\
\text { - Mood: } 7 \\
\text { - Walking ability: } 7 \\
\text { - Normal work: } 9 \\
\text { - Relationships: } 7 \\
\text { - Sleep: } 3 \\
\text { - Enjoyment of life: } 10\end{array}$ & $\begin{array}{l}\text { Primary care physician } \\
\text { Oncologist } \\
\text { Palliative care } \\
\text { specialist } \\
\text { Anesthesiologist }\end{array}$ & $\begin{array}{l}\text { Paracetamol }^{\mathrm{a}} \\
\text { Steroids }^{\mathrm{a}} \\
\text { Opioids }^{\mathrm{a}} \\
\text { Antiepileptics }^{\mathrm{a}} \\
\text { Antidepressants }^{\mathrm{a}} \\
\text { Chemotherapy }^{\mathrm{a}} \\
\text { Palliative pelvic radiation }\end{array}$ \\
\hline 5 & 72 , female & $\begin{array}{l}\text { Pancreatic cancer with liver } \\
\text { metastases. Eleven-month } \\
\text { history of phantom-limb pain } \\
\text { after a below-the-knee } \\
\text { amputation due to non-healing } \\
\text { ulcers from peripheral vascular } \\
\text { disease. }\end{array}$ & $16 / 38$ & $\begin{array}{l}\text {-General activity: } 5 \\
\text { - Mood: } 5 \\
\text { - Walking ability: } 5 \\
\text { - Normal work: } 6 \\
\text { - Relationships: } 5 \\
\text { - Sleep: } 5 \\
\text { - Enjoyment of life: } 5\end{array}$ & $\begin{array}{l}\text { Primary care physician } \\
\text { Orthopedic surgeon } \\
\text { Rehabilitation } \\
\text { physician } \\
\text { Anesthesiologist }\end{array}$ & $\begin{array}{l}\text { Paracetamol }^{\mathrm{a}} \\
\text { NSAIDs } \\
\text { Steroids } \\
\text { Opioids }^{\mathrm{a}} \\
\text { Antiepileptics }^{\mathrm{a}} \\
\text { Benzodiazepines }^{\mathrm{a}} \\
\text { Physical therapy }^{\mathrm{a}}\end{array}$ \\
\hline
\end{tabular}

\footnotetext{
a Treatments still in use at the time of the patients' first infusion of cetuximab.

b According to the Pain Detect tool, a score between 19 and 38 makes a neuropathic component of pain more than $90 \%$ probable. A score between 13 and 18 is indeterminate, with a $15-90 \%$ likelihood of a component of neuropathic pain [10].
}

complex regional pain syndrome type I(CRPS1), failed back surgery syndrome, phantom-limb pain (PLP) and cancerous invasion of sacral nerve roots. Baseline characteristics, previous treatments and physical findings of the patients are summarized in Table 1 and Fig. 1.

\subsection{Response to treatment}

The patients were asked to complete a BPI short form [11,12] daily, just before and during the EGFR inhibition, in order to document their neuropathic pain and thus, help us to judge their responses and guide treatment decisions. The responding patients' scores are summarized in Fig. 2. We report follow-up of 78-219 days for those who have responded to treatment.

Case 1 was given three weekly infusions of cetuximab. The treatment had no effect on the patient's NP and treatment was discontinued (data not shown).

Case 2 was given weekly infusions of cetuximab (Fig. 2, red arrows). Within $24 \mathrm{~h}$ after the first cetuximab dose, she experienced complete pain relief. After three weekly infusions of cetuximab, treatment with the monoclonal antibody panitumumab was attempted (Fig. 2, blue arrow). This EGFR-inhibitor is administered biweekly and was given in an attempt to simplify the treatment. However, the patient reported recurrence of severe pain on the very same evening as the panitumumab infusion. She received a therapeutically successful infusion of cetuximab the following day. After a total of six infusions of cetuximab, EGFRinhibition was converted to the oral small molecule inhibitor, gefitinib, so that the patient could be free to travel abroad.

Gefitinib was started seven days after the last cetuximab infusion and the patient continued to be free of NP. EGFR inhibition has had no effect on the vasomotor symptoms that accompany CRPS1. However, the pain relief has enabled her to comply with physiotherapy, which was previously hampered by extreme pain. As a consequence, there is indirect improvement in the edema that otherwise complicates her condition and that can lead to permanent disability.

Nineteen weeks after her first gefitinib dose, and 25 weeks after her first cetuximab infusion, the patient's NP continued to be completely relieved, but she developed elevated liver transaminases. Gefitinib was discontinued and within $48 \mathrm{~h}$, her excruciating pain recurred (see Fig. 2). Intravenous panitumumab was again attempted (see blue arrow, Fig. 2). This time she had not been given cetuximab shortly beforehand and she experienced pain relief within hours.

Case 3 was given two weekly infusions of cetuximab (Fig. 2, red arrows). Within hours after the first infusion, his severe and persistent pain was reduced significantly and it disappeared completely 

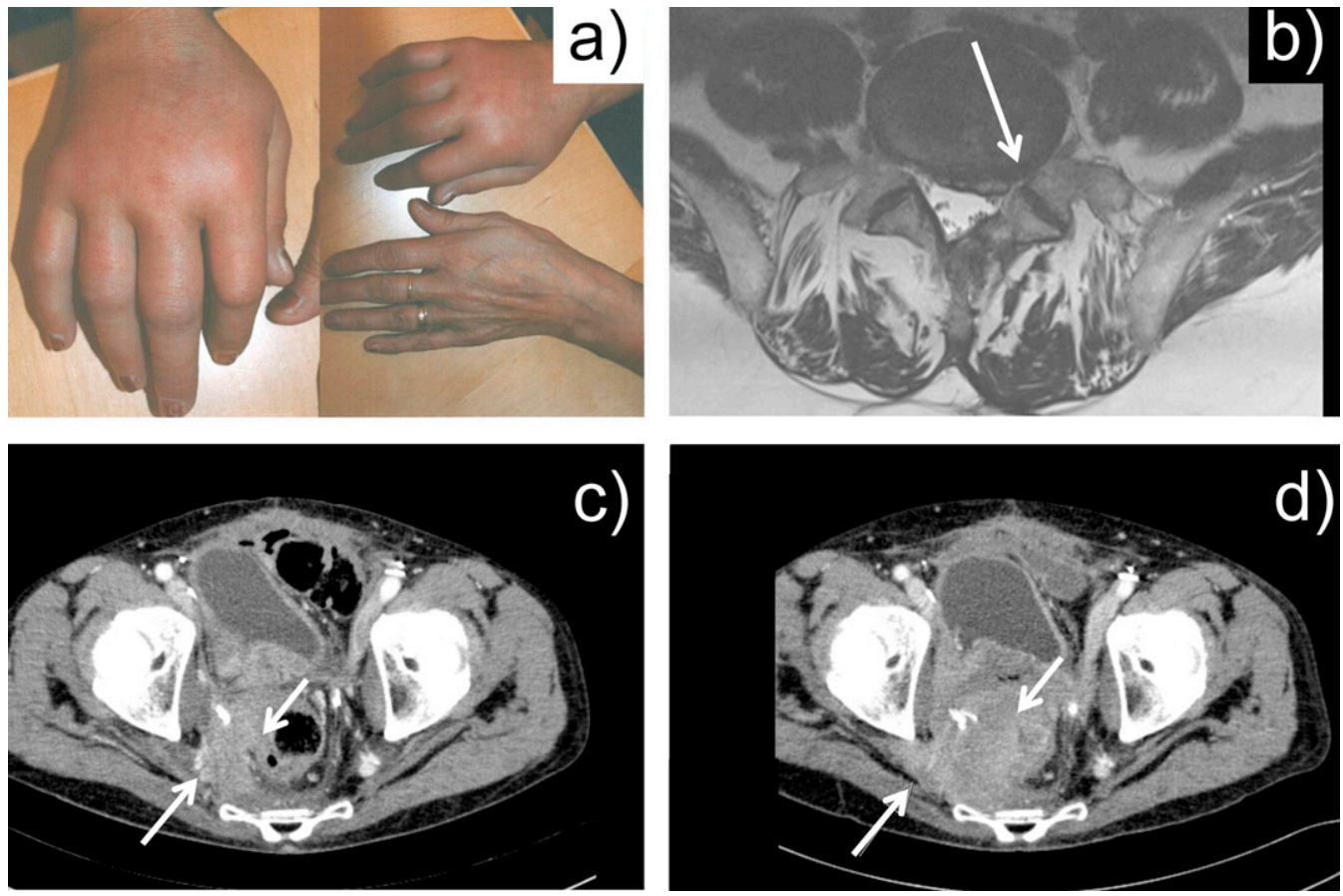

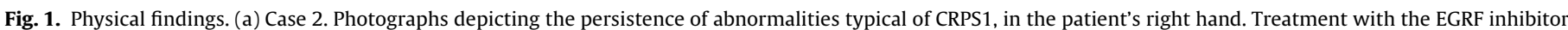

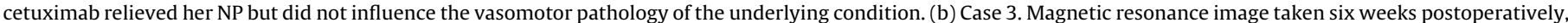

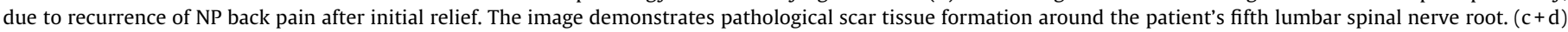

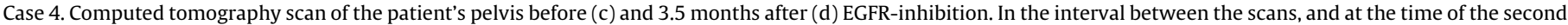
scan, the patient was completely relieved of his NP despite a growing pelvic tumor which increasingly invaded sacral nerves.

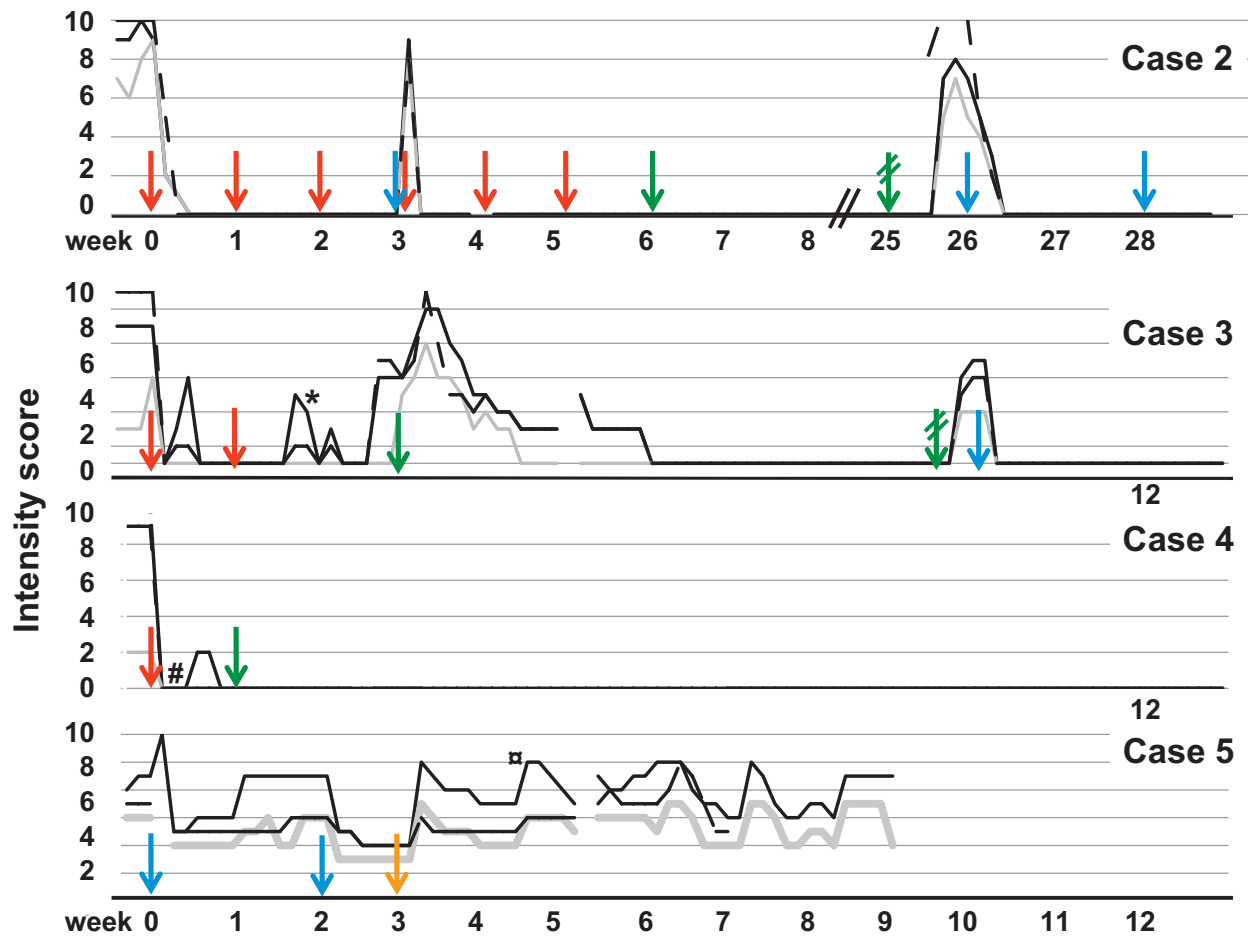

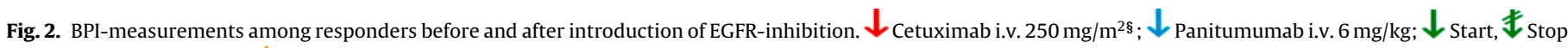
Gefitinib p.o. $250 \mathrm{mg}$ daily; $\vee$ Start Erlotinib p.o. $150 \mathrm{mg}$ daily. ${ }^{\S}$ First dose of cetuximab given as $400 \mathrm{mg} / \mathrm{m}^{2}$ loading dose; ${ }^{*}$ more pain due to intensive physical activity, no

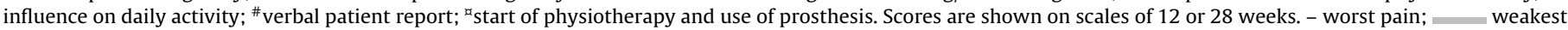
pain; - - - influence on daily activity. (For interpretation of the references to color in this figure legend, the reader is referred to the web version of the article.) 
within the following days. After his second dose of cetuximab, the patient waited to start a new treatment until the pain recurred, on day eleven.

At that stage, treatment was converted to gefitinib tablets (Fig. 2, green arrow). His pain continued to increase for the first two days of oral treatment. However, from the third day of gefitinib, the pain gradually improved to levels as good as those he had experienced with cetuximab. The patient's NP was so well-controlled that he could resume his former active lifestyle. One month after starting gefitinib he developed pneumonia. A mild degree of dyspnea persisted after its treatment and early interstitial lung disease (ILD) could not be excluded. Gefitinib was therefore discontinued (see Fig. 2) and NP recurred after three days. A dose of panitumumab was subsequently given with effective pain relief on the very same evening. When, after approximately three weeks, his pain recurred, pregabalin at a dose of $75 \mathrm{mg}$ twice daily was attempted. He had previously been unsuccessfully treated with gabapentin, but due to the uncertainty surrounding the possibility of ILD, an attempt at further conventional treatment was felt to be warranted before continued treatment with an alternative oral EGFR inhibitor. The patient responded to pregabalin, and continues to be pain-free at 28 weeks follow-up.

Case 4 was given cetuximab after treatment with the combination of gabapentin, amitriptyline, paracetamol, steroids, and titration to a 24-h morphine-equivalent dose of $1800 \mathrm{mg}$ failed to control his NP. Within hours after the infusion of the EGFR inhibitor, the patient experienced complete relief of his NP for the first time in over six months. Just three days after the first cetuximab treatment, his opioid and gabapentin doses were reduced by $50 \%$, limited only by the fear of abstinence symptoms and rebound effects. Cetuximab was converted to oral gefitinib at the time of the next planned treatment (Fig. 2, green arrow). Complete relief from NP was maintained despite progressive tumor invasion of pelvic nerves (see Fig. 1). His neuropathic pain continues to be completely relieved by gefitinib at 27 weeks of follow-up.

Case 5 received panitumumab while she was being treated with palliative gemcitabine for metastatic pancreatic cancer. Despite symptomatic cancer, chronic PLP radiating down her left leg was her major complaint. She had developed stump atrophy, contractures and pain which prohibited the use of her prosthesis. Within hours after the infusion of panitumumab, her PLP decreased to $50 \%$ (see Fig. 2). She subsequently required less breakthrough pain medication, was able to sleep through the night and her quality of lifeimproved. The intensity of worst pain recurred to baseline levels after one week, but was again alleviated within one day after the second infusion of panitumumab.

Erlotinib is an oral EGFR-inhibitor approved for treatment of pancreatic cancer. Panitumumab was therefore replaced by erlotinib after an analgesic response was observed (Fig. 2, orange arrow). Again, the patient reported PLP improvement with erlotinib, but this is not clearly conveyed in her BPI measurements (see Fig. 2). Her opioid requirement diminished and she was able to use her prosthesis for the first time since her amputation. However, swelling and contractures around her knee joint made its use extremely painful, but for the first time, it was possible. BPI scores therefore reflect both prosthesis pain and variations in abdominal pain from pancreatic cancer. PLP is no longer her major complaint, while her pancreatic cancer has remained radiologically stable.

\subsection{Side effects}

Cases 1, 2, 3 and 5 experienced mild acneiform rash and dry skin. These side effects were largely self-limiting, the acne resolving with the use of oral tetracycline. Case 2 developed elevation of liver transaminases during gefitinib treatment. They reached four times the upper limit of normal after four months of gefitinib and then normalized within a month after its discontinuation. Case 3 developed unilateral iridocyclitis after his first infusion of cetuximab, and again after infusion of panitumumab. He required treatment with topical steroids and cyclopentolate, and this also resolved completely. We could not entirely rule out the rare side effect of ILD after a bacterial pneumonia in case 3 . His lung function tests normalized within two weeks, without specific treatment, making an ILD less likely. Case 4 developed grade 3 aseptic meningitis on the same day as his infusion of cetuximab. He was admitted to the intensive care unit but the condition proved to be self-limiting and he was discharged, completely recovered, after five days. Both iridocyclitis and acute aseptic meningitis have previously been described in the literature as rare and transient, despite continued EGFR-inhibition $[13,14]$.

\section{Discussion}

We suggest the relief of NP to be a potential class effect of EGFR-inhibitors, since all four tested drugs were effective. The successful analgesic treatment of NP in four patients with different underlying mechanisms of pain is consistent with the effect described in our previous report [8]. Four of the five patients offered this treatment experienced dramatic and rapid analgesic responses after long-standing NP refractory to standard treatments.

Both extracellular (cetuximab and panitumumab) and intracellular (gefitinib and erlotinib) EGFR-inhibition led to NP relief.

Further support for a genuine drug effect is derived from clinical observations in case 3 whereby his pain recurred 11 days after cetuximab and roughly 20 days after panitumumab infusions, consistent with the half life of these drugs $[15,16]$ and with observations from our previously reported case [8]. The fact that the patient's pain responded more slowly to the oral drug than to intravenous administration of both cetuximab and panitumumab also supports the hypothesized causal and direct effect of EGFR inhibition.

Case 2 reported a dramatic increase in pain just hours after infusion of the anti-EGFR antibody panitumumab. A recent study has demonstrated that cetuximab and panitumumab hinder each other's EGFR binding [17]. This interaction may have played a role in the rapid recurrence of pain observed in this case. She experienced complete pain relief after treatment with panitumumab when she was in pain and had not been given cetuximab shortly beforehand.

All anti-EGFR drugs employed in these patients were developed to inhibit EGFR1-activation and, amongst others, MAPK-signaling by EGF in cancers. The observed effect may be due to inhibition of EGF, but by blocking EGFR1, these drugs also have the potential to inhibit other EGFR1-binding ligands, either directly or by inhibition of human epidermal growth factor receptor (HER) family heterodimerization [9]. It is in that respect of interest, that the neuregulin 1-ErbB3-ErbB2 complex has recently been suggested to be a causal mechanism in mechanical injury-induced trigeminal NP in rats [18].

Several receptor tyrosine kinases (RTKs) have the potential to activate MAPK-signaling, which has been proposed as a target for therapies directed against NP, as well as other chronic neurological diseases [7,19]. After nerve injury, neurons upregulate members of the HER-family of receptors [20,21], thereby potentially increasing their activation of the MAPK signaling [7] cascade. This may lead to further interaction between cells in the neuropathic pain triad [6]. We have therefore previously hypothesized a direct inhibition of MAPK-signaling by cetuximab in neuronal or glial cells [8].

Neuregulin is an important regulator of the neuropathic pain triad [22]. Expression changes in neuregulin 1 isoforms in NP model rats suggest a link between the EGFR and NP [23]. Furthermore, 
neuregulin signaling pathways have been shown to be biomarkers of cetuximab efficacy [24].

All four responding patients experienced some degree of transient side effects from the EGFR inhibitors. Despite this, continued anti-EGFR treatment was felt to be appropriate because of the significant impact that it had had on their pain, function and future prospects. After many months of excrutiating NP, leading to severely impaired physical and psychosocial functioning, all four responding patients almost immediately regained a QOL that was previously unimaginable.

\section{Conclusion}

EGFR-inhibition resulted in dramatic relief of NP in four of five patients with severe, long-standing and treatment-refractory NP. A plausible biological explanation involves the interruption of MAPKsignaling by EGFR-inhibition. The role of EGFR-inhibition as a target for the treatment of neuropathic pain appears promising and studies evaluating its therapeutic potential are warranted.

\section{Conflict of interest statement}

The authors have received a grant from the South-Eastern Norway Regional Health Authority and have filed a US provisional patent application for the use of EGFR as a clinical target for treatment of neurological disorders. There are no other potential conflicts of interest.

\section{References}

[1] Jensen TS, Baron R, Haanpää M, Kalso E, Loeser JD, Rice AS, Treede RD. A new definition of neuropathic pain. Pain 2011;152:2204-5.

[2] Finnerup NB, Sindrup SH, Jensen TS. The evidence for pharmacological treatment of neuropathic pain. Pain 2010;150:573-81.

[3] Jensen MP, Chodroff MJ, Dworkin RH. The impact of neuropathic pain on healthrelated quality of life: review and implications. Neurology 2007;68:1178-82.

[4] Dieleman JP, Kerklaan J, Huygen FJ, Bouma PA, Sturkenboom MC. Incidence rates and treatment of neuropathic pain conditions in the general population. Pain 2008; 137:681-8.

[5] Bouhassira D, Lantéri-Minet M, Attal N, Laurent B, Touboul C. Prevalence of chronic pain with neuropathic characteristics in the general population. Pain 2008;136:380-7.

[6] Scholz J, Woolf CJ. The neuropathic pain triad: neurons, immune cells and glia. Nat Neurosci 2007;10:1361-8.
[7] Ji RR, Gereau RW 4th, Malcangio M, Strichartz GR. MAP kinase and pain. Brain Res Rev 2009;60:135-48.

[8] Kersten C, Cameron MG. Cetuximab alleviates neuropathic pain despite tumour progression. BMJ Case Rep 2012;2012.

[9] Yarden Y, Pines G. The ERBB network: at last, cancer therapy meets systems biology. Nat Rev Cancer 2012;12:553-63.

[10] Freynhagen R, Baron R, Gockel U, Tölle TR. painDETECT: a new screening questionnaire to identify neuropathic components in patients with back pain. Curr Med Res Opin 2006;22:1911-20.

[11] Klepstad P, Loge JH, Borchgrevink PC, Mendoza TR, Cleeland CS, Kaasa S. The Norwegian brief pain inventory questionnaire: translation and validation in cancer pain patients. J Pain Symptom Manage 2002;24: 517-25.

[12] Keller S, Bann CM, Dodd SL, Schein J, Mendoza TR, Cleeland CS. Validity of the brief pain inventory for use in documenting the outcomes of patients with noncancer pain. Clin J Pain 2004;20:309-18.

[13] Feinstein TM, Gibson MK, Argiris A. Cetuximab-induced aseptic meningitis. Ann Oncol 2009;20:1609-10.

[14] Basti S. Ocular toxicities of epidermal growth factor receptor inhibitors and their management. Cancer Nurs 2007;30(Suppl. 1):S10-6.

[15] Ramanathan RK. Alternative dosing schedules for cetuximab: a role for biweekly administration? Clin Colorectal Cancer 2008;7:364-8.

[16] Saadeh CE, Lee HS. Panitumumab: a fully human monoclonal antibody with activity in metastatic colorectal cancer. Ann Pharmacother 2007;41:606-13.

[17] Alvarenga ML, Kikhney J, Hannewald J, Metzger AU, Steffens KJ, Bomke J, Krah A, Wegener A. In-depth biophysical analysis of interactions between therapeutic antibodies and the extracellular domain of the epidermal growth factor receptor. Anal Biochem 2012;421:138-51.

[18] Ma F, Zhang L, Westlund KN. Trigeminal nerve injury ErbB3/ErbB2 promotes mechanical hypersensitivity. Anesthesiology 2012;117(2):381-8.

[19] Yasuda S, Sugiura H, Tanaka H, Takigami S, Yamagata K. p38 MAP kinase inhibitors as potential therapeutic drugs for neural diseases. Cent Nerv Syst Agents Med Chem 2011;11:45-59.

[20] Liu B, Neufeld AH. Activation of epidermal growth factor receptors in astrocytes: from development to neural injury. J Neurosci Res 2007;85:3523-9.

[21] Carroll SL, Miller ML, Frohnert PW, Kim SS, Corbett JA. Expression of neuregulins and their putative receptors, ErbB2 and ErbB3, is induced during Wallerian degeneration. J Neurosci 1997;17:1642-59.

[22] Calvo M, Zhu N, Grist J, Ma Z, Loeb JA, Bennett DL. Following nerve injury neuregulin-1 drives microglial proliferation and neuropathic pain via the MEK/ERK pathway. Glia 2011;59:554-68

[23] Kanzaki H, Mizobuchi S, Obata N, Itano Y, Kaku R, Tomotsuka N, Nakajima H, Ouchida M, Nakatsuka H, Maeshima K, Morita K. Expression changes of the neuregulin 1 isoforms in neuropathic pain model rats. Neurosci Lett 2012;508:78-83.

[24] Oliveras-Ferraros C, Vazquez-Martin A, Queralt B, Adrados M, Ortiz R, Cufí S Hernández-Yagüe X, Guardeño R, Báez L, Martin-Castillo B, Pérez-Martínez MC, Lopez-Bonet E, De Llorens R, Bernadó L, Brunet J, Menendez JA. Interferon/STAT1 and neuregulin signaling pathways are exploratory biomarkers of cetuximab (Erbitux(R)) efficacy in KRAS wild-type squamous carcinomas: a pathway-based analysis of whole human-genome microarray data from cetuximab-adapted tumor cell-line models. Int J Oncol 2011;39: 1455-79. 